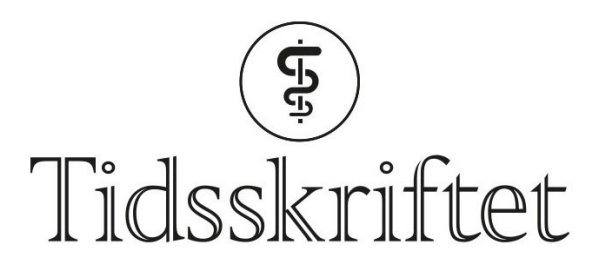

DEN NORSKE LEGEFORENING

\title{
Kolleger drept i Gaza
}

DEBATT

HANNE HESZLEIN-LOSSIUS

E-post: hannelossius@gmail.com

Hanne Heszlein-Lossius er ph.d., lege i spesialisering i anestesi ved Haukeland universitetssjukehus og kommunelege i Berlevåg.

Forfatteren har fylt ut ICMJE-skjemaet og oppgir ingen interessekonflikter.

\section{SIDSEL GILBERT}

Sidsel Gilbert er psykiater ved Dr Gilberts spesialistpraksis, Oslo.

Forfatteren har fylt ut ICMJE-skjemaet og oppgir ingen interessekonflikter.

\section{MINA ADAMPOUR}

Mina Adampour er lege i spesialisering i nevrologi ved Akershus universitetssykehus. Forfatteren har fylt ut ICMJE-skjemaet og oppgir ingen interessekonflikter.

\section{INGER SANDANGER}

Inger Sandanger er ph.d. og pensjonert spesialist i psykiatri.

Forfatteren har fylt ut ICMJE-skjemaet og oppgir ingen interessekonflikter.

\section{ANNE BERIT GUTTORMSEN}

Anne Berit Guttormsen er professor og overlege i intensivmedisin ved Haukeland universitetssjukehus.

Forfatteren har fylt ut ICMJE-skjemaet og oppgir ingen interessekonflikter.

\section{GRETE ALREK IVERSEN}

Grete Alrek Iversen er overlege i gynekologi ved Kvinneklinikken, Haukeland universitetssjukehus. Forfatteren har fylt ut ICMJE-skjemaet og oppgir ingen interessekonflikter.

\section{VEGARD ANDERSEN}

Vegard Andersen er medisinstudent.

Forfatteren har fylt ut ICMJE-skjemaet og oppgir ingen interessekonflikter.

\section{VILDE RAVNSBORG GURIGARD}

Vilde Ravnsborg Gurigard er medisinstudent.

Forfatteren har fylt ut ICMJE-skjemaet og oppgir ingen interessekonflikter.

\section{METTE LØKELAND}

Mette Løkeland er ph.d. og overlege i fødselshjelp og kvinnesykdommer ved Kvinneklinikken, Haukeland universitetssjukehus.

Forfatteren har fylt ut ICMJE-skjemaet og oppgir ingen interessekonflikter. 
Svein Are Osbakk er luftambulanselege og overlege i anestesi ved Oslo universitetssykehus.

Forfatteren har fylt ut ICMJE-skjemaet og oppgir ingen interessekonflikter.

\section{TORI HUSUM}

Tori Husum er lege i spesialisering i gynekologi ved Kvinneklikken, Haukeland universitetssjukehus. Forfatteren har fylt ut ICMJE-skjemaet og oppgir ingen interessekonflikter.

\section{MARIT TUV}

Marit Tuv er kommuneoverlege og fastlege ved Vang legesenter.

Forfatteren har fylt ut ICMJE-skjemaet og oppgir ingen interessekonflikter.

\section{GRO LILLEGRAVEN}

Gro Lillegraven er overlege ved Medisinsk avdeling, Voss sjukehus. Forfatteren har fylt ut ICMJE-skjemaet og oppgir ingen interessekonflikter.

\section{KRISTINE WAERHAUG}

Kristine Wærhaug er overlege i anestesi ved Anestesiavdelingen, Universitetssykehuset i Nord-Norge. Forfatteren har fylt ut ICMJE-skjemaet og oppgir ingen interessekonflikter.

\section{EBBA WERGELAND}

Ebba Wergeland er forsker og spesialist i arbeidsmedisin.

Forfatteren har fylt ut ICMJE-skjemaet og oppgir ingen interessekonflikter.

\section{EMMELINN BRÅTANE}

Emmelinn Bråtane er kommuneoverlege i Lurøy kommune.

Forfatteren har fylt ut ICMJE-skjemaet og oppgir ingen interessekonflikter.

\section{LIVE HELBEK}

Live Helbæk er lege i spesialisering i pediatri ved Oslo universitetssykehus. Forfatteren har fylt ut ICMJE-skjemaet og oppgir ingen interessekonflikter.

Helseinstitusjoner er skadd og kolleger drept i målrettede militære angrep mot Gaza under den pågående pandemien.

Du vil aldri forstå det med mindre du har levd det.Jeg har delt familien min $i$ to. Nå bor jeg med halve familien $i$ en adskilt del av huset. Min kone og resten av familien bor i en annen del. Vi har gjort det slikfor å sikre oss at noen overlever dersom Israels militcre bomber familiehjemmet vårt. Det kostet timer og tårer å bestemme hvem som skulle bo sammen og hvor. Hva hvis min avgjørelse om hvor mine barn sover ender opp med å koste dem livet? Vennene mine sier det er best å dø sammen. Men hvorfor skal vi alle dø, hvis det er mulig å redde en liten andel av oss?

Teksten ble skrevet i Gaza 17. mai da vi feiret Norges nasjonaldag ( sitatet er hentet fra en twittermelding skrevet av Khalil Saleem). Mens vi feiret friheten og freden vi tar for gitt, ble sivile og våre egne kollegaer drept i massive bombeangrep på Gazastripen. Teksten nådde oss like etter nyhetene om at Gazas helsedepartement ble bombet. I tillegg ble deler av Gazas primærhelsetjeneste og Al-Rimal-klinikken, som drev Gazas viktigste covid-19laboratorium skadet. Der var allmennlegen dr. Salah på jobb. Han ble livstruende skadd av bombesplinter. Koronatester kan ikke lenger analyseres (1). I Gaza er bare 1,9\% av befolkningen fullvaksinert. I Israel er andelen $56 \%$ (2).

\section{Helsevesenet og sivile rammes}

Natt til 16. mai ble dr. Ayman Abu al-Ouf, drept sammen med tolv andre nære familiemedlemmer da israelske jagerfly bombet familiens hjem i Gaza by (3). Han var avdelingsoverlege ved medisinsk avdeling på Shifa-sykehuset og leder for covid-arbeidet i Gaza (3). Samme natt ble også nevrologen dr. Muin al-Aloul drept i sitt hjem sammen med sin ektefelle, psykologen Raja al-Aloul og parets fem barn (1). 
Angrepene på tett befolkede boligområder har drevet 107 ooo mennesker på flukt fra egne hjem

Fra 10. mai til våpenhvilen 21. mai er minst 243 palestinere drept i Gaza. Blant de drepte er 66 barn og 38 kvinner; 14 familier har mistet tre eller flere familiemedlemmer. I Israel er tolv mennesker drept hvorav to er barn og fire kvinner. Nær 2 ooo Gaza-palestinere er skadet i de israelske angrepene, i Israel 710. Omfattende angrep på Gazas infrastruktur, som hovedveien til Al-Shifa sykehuset, forsinker ambulansetransport av skadde. Seks lokale sykehus og elleve klinikker er ifølge FN ødelagt (4). Angrepene på tett befolkede boligområder har drevet 107000 mennesker på flukt fra egne hjem.

Alt dette skjer mens pandemien i Gaza har ført til en tredje smittebølge der 20-40 \% av Gazas innestengte befolkning tester positivt på korona. Over 100 korona-pasienter krever intensivbehandling $(5,6)$.

En våpenhvile trådte i kraft natt til 21. mai (7). Men vi vet at det vil komme ny krigføring, så lenge de underliggende årsakene vedvarer: israelsk okkupasjon, landrøveri, og Gazablokaden. Israels forbrytelser mot menneskeheten og apartheidregimet er godt dokumentert, senest av Human Rights Watch i april 2021, uten at Norge bruker sine muligheter til å få stoppet dette (8).

\section{Vi krever at kolonisering, apartheid og krigføring må opphøre}

Sammen med kolleger over hele verden protesterer vi mot Israels krigføring mot Gazas befolkning og helsevesen. Helsearbeidere fra flere land krever at israelsk kolonisering og apartheidpolitikk må opphøre (9). Vi ber Legeforeningen oppfordre våre kollegaer i den israelske legeforeningen til å kreve rettferdighet og trygghet for sine palestinske kollegaer selv om det er våpenhvile! Vi ber også om at Legeforeningen henvender seg til World Medical Assosciation (WMA) for en klar fordømmelse av angrepene på Gazas helsepersonell, på lik linje med deres tydelige støtte til helsepersonell som angripes i Myanmar (10).

Sammen med kolleger over hele verden protesterer vi mot Israels krigføring mot Gazas befolkning og helsevesen

Som leger ber vi regjeringen ta ansvar som medlem av FNs sikkerhetsråd og kreve at Israel opphever den 14 år lange og folkerettsstridige blokaden av Gaza, stanser alle militære angrep på sivile, og respekterer folkeretten. Vi godtar ikke at våre kolleger drepes, at helseinstitusjoner bombes, eller at befolkningen mister sin rett til helse (11).

LITTERATUR:

1. Kruhaug NI. Norske helsearbeidere hardt ut mot Israel. Aftenbladet 19.5.2021. https://www.aftenbladet.no/utenriks/i/GapGP6/norske-helsearbeidere-hardt-ut-mot-israel Lest 4.6.2021.

2. An Israeli airstrike damaged Gaza's only lab for processing coronavirus tests, officials said. The New York Times 18.5.2021.

https://www.nytimes.com/2021/05/18/world/middleeast/israel-gaza-covid-lab.html Lest 4.6.2021.

3. Shaikhouni L. 'His death is a catastrophe': Gaza doctors mourn specialist killed in air strike. BBC 20.5.2021. https://www.bbc.com/news/world-middle-east-57148580 Lest 4.6.2021.

4. United Nations Office for the Coordination of Humanitarian Affairs. Gaza Strip: Escalation of hostilities 10-21 May 2021.

https://www.ochaopt.org/content/gaza-strip-escalation-hostilities-10-21-may-2021 Lest 4.6.2021.

5. al-Hajjar M, Hussaini M. Gaza's main Covid-19 lab halts tests after Israel

bombing. https://www.middleeasteye.net/news/gaza-covid-ceases-operations-israel-strike Lest 
4.6.2021.

6. Press release 20/05-21 by Dr. Abdul Latif Haji Director-General of International Cooperation at the Ministry of Health Gaza, Palestine.

7. Department of Operational Support. UN chief welcomes Gaza ceasefire announcement between Israel and Hamas.

https://operationalsupport.un.org/en/un-chief-welcomes-gaza-ceasefire-announcement-between-israe l-and-hamas\#: :text-

The\%2oUN\%2ochief\%2ohas\%2owelcomed,occupied\%2oPalestinian\%2oenclave\%2oof\%2oGaza. Lest 4.6.2021.

8. Human Rights Watch. Israeli Authorities and the Crimes of Apartheid and Persecution. https://www.hrw.org/report/2021/04/27/threshold-crossed/israeli-authorities-and-crimes-apartheid-an d-persecution Lest 4.6.2021.

9. Palestine \& Praxis. https://palestineandpraxis.weebly.com/ Lest 4.6.2021.

10. World Medical Association. WMA Council Resolution in Support of Medical Personnel and Citizens of Myanmar.

https://www.wma.net/policies-post/wma-council-resolution-in-support-of-medical-personnel-and-citi zens-of-myanmar/ Lest 4.6.2021.

11. We For Gaza. Open letter to the British Medical Journal.

http://we4gaza.org/2021/05/17/open-letter-to-the-british-medical-journal/ Lest 4.6.2021.

Publisert: 8. juni 2021. Tidsskr Nor Legeforen. DOI: 10.4045/tidsskr.21.0431

(C) Tidsskrift for Den norske legeforening 2020. Lastet ned fra tidsskriftet.no 